\title{
Effects of dietary fat source on physical, chemical and sensorial quality of calves' meat
}

\author{
M. Zymon' ${ }^{1}$, J. Strzetelski ${ }^{1,3}$ and J. Kowalczyk ${ }^{2}$ \\ ${ }^{I}$ National Research Institute of Animal Production, \\ Department of Animal Nutrition and Feed Science \\ 32-083 Balice, Poland \\ ${ }^{2}$ The Kielanowski Institute of Animal Physiology and Nutrition, Polish Academy of Sciences \\ 05-110 Jablonna, Poland
}

\begin{abstract}
The effects of including rape seed (10\%) and fish oil (4\%) into the diet for 30 calves (7-90 days of life) on the physical, chemical and sensorial quality of meat were investigated. The analyses encompassed nutrient content in the diet, $\mathrm{pH}$, colour and tenderness measurement, and evaluation of sensorial properties such as texture, tenderness, flavour, tastiness and juiciness. Fat supplementation had no significant effect on the chemical and physical properties of meat. Rape seed did not change the sensorial quality of meat, in contrast to fish oil, which deteriorated the texture, flavour and tastiness of meat.
\end{abstract}

KEY WORDS: calf, fish oil, rape seed, meat, sensorial quality

\section{INTRODUCTION}

Meat from ruminants is a major source of essential nutrients for humans (amino acids, iron, zinc and B-group vitamins) but contains excess saturated fat, which can be a major risk for the development of coronary heart disease (Williams, 2000). Feeding calves diets high in unsaturated fatty acids, especially n-3 and n-6 PUFA, can improve the health quality of meat (Zymon et al., 2005; Zymon and Strzetelski, 2006) but not necessarily its sensory value. Ruminant meat is an attractive type of food, especially because of its sensory quality traits: colour, tenderness, flavour and juiciness. These tissue characteristics depend on many breeding factors including nutrition, physiological state and genetic type of the animal, as well as rearing systems (grass- or grain-fed) of animals (Geay et al., 2002). The aim of this study was to determine the effect of rape seed or fish oils as

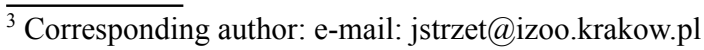


a fat supplement to calf diets on the dietary value of meat, physical and chemical traits and sensory qualities of calf meat.

\section{MATERIAL AND METHODS}

Thirty Black-and-White bull calves, aged from 7 to 90 days, were randomly divided into 3 equal groups. Calves were fed ad libitum a concentrate without or with rape seed or fish oil (Table 1). For the first 56 days the calves also received a milk replacer. At the end of the experiment the calves were slaughtered and samples of meat from the Musculus thoracis were taken for analysis. The nutrient content of meat was determined by standard procedures (AOAC, 1998). $\mathrm{pH}$ was measured $45 \mathrm{~min}$ and $24 \mathrm{~h}$ after slaughter, meat colour was determined according to the CIE L*a*b* system (Boccard et al., 1981). After 48-h cooling of meat samples, thermal weight loss and tenderness were measured (Joseph, 1979). Meat samples were sliced into $1.5 \mathrm{~cm}$ thick steaks and cooked at $165^{\circ} \mathrm{C}$ to an internal temperature of $70^{\circ} \mathrm{C}$. Sensory evaluation was performed according to a 5-point scale (Baryłko-Pikielna, 1975). The results were analysed statistically using the one-way analysis of variance procedure of SAS (Enterprise Guide, 2002). The differences were assumed to be not significant at $\mathrm{P}>0.05$.

Table 1. Composition of concentates, $\%$

\begin{tabular}{lccc}
\hline \multirow{2}{*}{ Feeds } & \multicolumn{3}{c}{ Groups } \\
\cline { 2 - 4 } & control & rape seed & fish oil \\
\hline Ground barley & 40.5 & 55.5 & 40.5 \\
Ground wheat & 30.5 & 13 & 27 \\
Wheat bran & 13 & 6 & 10 \\
Soyabean meal & 13 & 12.5 & 15.5 \\
Rape seed Spencer, ground & & 10 & \\
Fish oil & & & 4 \\
Minerals & 3 & 3 & 3 \\
\hline
\end{tabular}

${ }_{1}^{1}$ complet CJ; in $1 \mathrm{~kg}, \mathrm{~g}$ : $\mathrm{Ca} 212.8, \mathrm{P} 60, \mathrm{Na} 88, \mathrm{Mg} 25, \mathrm{Zn} 4, \mathrm{Mn} 2.5, \mathrm{Fe} 1.5$; IU: vit. E 0.8, vit. A 450000 , vit. $\mathrm{D}_{3} 100000$

\section{RESULTS}

No differences were found among groups in dry matter and protein contents, although a tendency towards a higher fat content in the meat of calves fed fish oil $(1.2 \% \mathrm{DM})$ than in those fed rape seed oil $(0.9 \% \mathrm{DM})$ and the control feed $(1.0 \% \mathrm{DM})(\mathrm{P}>0.05)$ was noted. The studied fat sources did not cause significant differences $(\mathrm{P}>0.05)$ in the physicochemical characteristics of meat (Table 2). A trend was noted, however, towards a decrease in thermal weight loss in meat from calves 
fed rape seed and fish oils. At the same time, however, this meat was characterized by a somewhat worse tenderness. Twenty-four $h$ after slaughter the meat of calves fed rape seed showed a tendency towards paler colour and lower yellow saturation, whereas $48 \mathrm{~h}$ after slaughter, to lower red saturation. After $48 \mathrm{~h}$ of cold storage, the meat from calves in all groups was characterized by a lighter colour and greater yellow saturation than meat in cold storage for $24 \mathrm{~h}$. In all groups the $\mathrm{pH}$ was on a uniform level, with a proportional decline notes after $24 \mathrm{~h}$.

Table 2. The physical properties of meat

\begin{tabular}{lrrrrr}
\hline \multirow{2}{*}{ Item } & \multicolumn{3}{c}{ Groups } & \multirow{2}{*}{ P } & \multirow{2}{*}{ SEM } \\
\cline { 2 - 4 } & control & rape seed & fish oil & & \\
\hline Thermal weight loss, \% & 32.15 & 27.31 & 29.06 & 0.40 & 1.44 \\
Tenderness, kg/cm & 13.29 & 17.96 & 15.44 & 0.13 & 0.94 \\
pH 45 min after slaughter & 5.88 & 5.96 & 5.99 & 0.57 & 0.04 \\
pH 24 h after slaughter & 5.74 & 5.78 & 5.71 & 0.66 & 0.03 \\
& & & & & \\
Colour 24 h after slaughter & & & & & \\
$\quad$ lightness (L) & 47.42 & 45.66 & 47.11 & 0.27 & 0.47 \\
$\quad$ redness (a) & 18.62 & 18.74 & 18.99 & 0.83 & 0.24 \\
$\quad$ yellowness (b) & 1.84 & 1.25 & 2.07 & 0.45 & 0.27 \\
Colour 48 h after slaughter & & & & & \\
$\quad$ lightness (L) & 49.06 & 49.01 & 50.65 & 0.28 & 0.47 \\
$\quad$ redness (a) & 18.54 & 16.01 & 18.43 & 0.21 & 0.65 \\
$\quad$ yellowness (b) & 3.86 & 3.53 & 3.70 & 0.92 & 0.32 \\
\hline P>0.05 & & & & &
\end{tabular}

It was found that the meat of calves fed fish oil had the least pleasant smell ( $\mathrm{P} \leq 0.05)$, despite its intensity being weaker than in other groups (Table 3 ). The fish-oil group also had the lowest structure and tastiness desirability scores $(\mathrm{P} \leq 0.05)$. Rape seed significantly improved the tastiness desirability of meat in comparison with fish oil $(\mathrm{P} \leq 0.05)$. In the group of calves fed rape seed, a tendency was noted towards a worse structure, but also towards greater flavour intensity and better juiciness of meat.

Table 3 . The sensory quality of meat

\begin{tabular}{|c|c|c|c|c|c|}
\hline \multirow{2}{*}{ Item } & \multicolumn{3}{|c|}{ Groups } & \multirow{2}{*}{$P$} & \multirow{2}{*}{ SEM } \\
\hline & control & rape seed & fish oil & & \\
\hline Texture & $3.67^{\mathrm{a}}$ & $3.31^{\mathrm{ab}}$ & $3.09^{\mathrm{b}}$ & 0.05 & 0.10 \\
\hline Flavour intensity & 3.72 & 3.60 & 3.32 & 0.11 & 0.08 \\
\hline Flavour desirability & $4.01^{\mathrm{a}}$ & $3.91^{\mathrm{a}}$ & $3.31^{\mathrm{b}}$ & 0.003 & 0.10 \\
\hline Tenderness & 3.52 & 3.52 & 3.15 & 0.28 & 0.11 \\
\hline Juiciness & 3.54 & 3.73 & 3.43 & 0.30 & 0.08 \\
\hline Tastiness intensity & 3.60 & 3.72 & 3.42 & 0.25 & 0.07 \\
\hline Tastiness desirability & $3.84^{\mathrm{a}}$ & $4.04^{\mathrm{a}}$ & $3.40^{\mathrm{b}}$ & 0.005 & 0.09 \\
\hline
\end{tabular}

$\mathrm{a}, \mathrm{b}-\mathrm{P} \leq 0.05$ 


\section{DISCUSSION}

The first trait that a client takes into account when buying meat is its colour. In this experiment, colour parameters were characteristic for veal (Sterrenburg et al., 1991), although in the case of feeding rape seed, the meat was slightly darker. Krełowska-Kułas et al. (1991) using a 30\% addition of crushed rape seed in feeds for young bulls showed that the meat was characterized by desirable colour traits. The lightening of colour and lowering of the $\mathrm{pH}$ that occurred after $48 \mathrm{~h}$ of cold storage was probably related to the post-slaughter acidification of meat, resulting in the formation of lactic acid. The rapid cooling of meat after slaughter lowers the intensity of glycolytic processes, and therefore the rate at which the $\mathrm{pH}$ declined in meat (Guignot et al., 1994). In ruminants, variations in diet composition allow some modifications in digestive processes, which regulate the nature and proportion of absorber nutrients and thereby affect meat tenderness (Geay et al., 2001). When rape seed and fish oil were fed, a tendency towards deterioration of meat tenderness in comparison with controls was found, although this change did not reach statistical significance. In the opinion of Hocquette et al. (1998) the differences in meat tenderness can be explained by the differences in growth rate and fattiness. Meat flavour can be modified by rearing animals using nutritional conditions which change fat contents and compositions or which change compounds involved in the Maillard reaction (Geay et al., 2001). The reason for the deterioration of the flavour and smell of the meat when fish oil was fed was probably the different fatty acid profile of the meat fat, which has a significant influence on the nature of the compounds arising during thermal processing of meat (Reineccius, 1994). The long-chain fatty acids in fish oil can bypass rumen biohydrogenation with minimal change (Scollan et al., 2004). This increase in unsaturation can lead to negative flavour perception. Juiciness depends on the degree of water binding by protein and on the content of intramuscular fat (Farmer, 1994). It is therefore difficult to explain why the least juicy was the meat from calves fed fish oil, despite the meat from this group having the highest fat level. According to some authors, the nature of the diet does not influence juiciness. Indeed, no significant difference has been observed in the juiciness of meat from young bulls fed either an lucerne silage diet or a concentrate diet (Mandel et al., 1998). Similarly, no significant difference in juiciness has been observed between grass-fed and grain-fed young bulls despite differences in carcass fatness and meat tenderness (Vestergaard et al., 2000). However, meat from muscles of young bulls fattened with hay is juicier than meat from muscle of bulls fed grass silage (Listrat et al., 1999). 


\section{CONCLUSIONS}

The results of the study demonstrate that feeding calves with different sources of fat has a distinct and not necessarily favourable effect on the physical, chemical and sensorial qualities of meat. Fish oil deteriorated the sensory properties of meat, especially texture, flavour and tastiness; this would probably be met with dissatisfaction by the consumer.

\section{REFERENCES}

AOAC, 1998. Association of Official Analytical Chemists, Official Methods of Analysis. 16 ${ }^{\text {th }}$ Edition. Gaithersburg, MD

Baryłko-Pikielna N., 1975. Methods of Sensonal Analysis of Food (in Polish). WNT Warszawa

Boccard R., Buchter L., Casteels E., Cosentino E., Dransfield E., Hood D.E., Joseph R.L., McDougall D.B., Rhodes D.N., Schön I., Timbergen B.J., Touraille C., 1981. Procedures for measuring meat quality characteristics in beef production experiments. Report of a Working Group in the Commission of the European Communities (CEC), Beef Production Research Programme. Livest. Prod. Sci. 8, 385-397

Farmer L.J., 1994. The role of nutrients in meat flavour formation. Proc. Nutr. Soc. 53, 327-333

Geay Y., Bauchart D., Hocquette J., Culioli J., 2001. Effect of nutritional factors on biochemical, structural and metabolic characteristics of muscles in ruminants, consequences on dietetic value and sensorial qualities of meat. Reprod. Nutr. Develop. 41, 1-26

Guignot F., Touraille C., Ouali A., Renerre M., Monin G., 1994. Relationships between post-mortem pH changes and some traits of sensory quality in veal. Meat Sci. 37, 315-325

Hocquette J.F., Ortigues-Marty I., Pethick D., Herpin P., Fernandez X., 1998. Nutritional and hormonal regulation of energy metabolism in skeletal muscles of meat-producing animals. Livest. Prod. Sci. 56, 115-143

Joseph R.L., 1979. Recommended method for assessment of tenderness. In: J.C. Bowman, P. Susmel (Editors). The Future of Beef Production in the European Community. Martinus Nijhoff, The Hague (The Netherlands). Curr. Top. Vet. Med. Anim. Sci. 5, 596-606

Krełowska-Kułas M., Kędzior W., Strzetelski J., 1991. The quality of meat and fat of young bulls fattened with a full ratio mixture containing ground rape seeds. Arch. Anim. Nutr. 41, 657-662

Listrat A., Rakadjiyski N., Jurie C., Picard B., Touraille C., Geay Y., 1999. Effect of the type of diet on muscle characteristics and meat palatability of growing Salers bulls. Meat Sci. 53, 115-124

Mandel I.B., Buchanan-Smith J.G., Campell C.P., 1998. Effects of forage vs. grain feeding on carcass characteristics, fatty acid composition and beef quality in Limousin-cross steers when time on feed is controlled. J. Anim. Sci. 76, 2619-2630

Reineccius G., 1994. Flavor and aroma chemistry. In: A.M. Pearson, T.R. Dutson (Editors). Quality Attributes and their Measurement in Meat, Poultry and Fish Products. Adv. Meat Res. 9, 184-201

Scollan N., Enser M., Richardson R.I., Gulati S., Hallett K.G., Nute G.R., Wood J.D., 2004. The effects of ruminally protected dietary lipid on the lipid composition and quality of beef muscle. In: Proceedings of the $50^{\text {th }}$ International Congress of Meat Science and Technology. Helsinki (Finland), p. 2.50

Sterrenburg P., Nijeboer H., De Boer T.J., 1991. Reproducibility of colour score as a result of classification of veal in the Netherlands. $37^{\text {th }}$ International Congress of Meat Science and Technology, Kulbach (Germany) 
Vestergaard M., Therkildsen M., Henckel P., Jensen L.R., Andersen H.R., Sejrsen K., 2000. Influence of feeding intensity, grazing and finishing feeding on meat and eating quality of young bulls and the relationship between muscle fibre characteristics, fibre fragmentation and meat tenderness. Meat Sci. 54, 187-196

Williams C.M., 2000. Dietary fatty acids and human health. Ann. Zootech. 49, 161-180

Zymon M., Strzetelski J., 2006. The effect of feeding two rapeseed cultivars differing in fatty acid profile on health promoting value of veal. Anim. Sci., Suppl. 1, 160-161

Zymon M., Strzetelski J.A., Kowalczyk J., 2005. The effect of fish oil in calf diets on the fatty-acid content of Musculus thoracis intramuscular fat. J. Anim. Feed Sci. 14, Suppl. 1, 319-322 